\title{
Gap-filling strategies for annual VOC flux data sets
}

\author{
I. Bamberger ${ }^{1, *}$, L. Hörtnagl ${ }^{2,}$, , M. Walser ${ }^{1}$, A. Hansel ${ }^{1}$, and G. Wohlfahrt ${ }^{2}$ \\ ${ }^{1}$ Institute of Ion Physics and Applied Physics, University of Innsbruck, Austria \\ ${ }^{2}$ Institute of Ecology, University of Innsbruck, Austria \\ *now at: Institute of Agricultural Sciences, ETH-Zurich, Switzerland \\ Correspondence to: G. Wohlfahrt (georg.wohlfahrt@uibk.ac.at)
}

Received: 15 October 2013 - Published in Biogeosciences Discuss.: 15 November 2013

Revised: 26 February 2014 - Accepted: 11 March 2014 - Published: 30 April 2014

\begin{abstract}
Up to now the limited knowledge about the exchange of volatile organic compounds (VOCs) between the biosphere and the atmosphere is one of the factors which hinders more accurate climate predictions. Complete longterm flux data sets of several VOCs to quantify the annual exchange and validate recent VOC models are basically not available. In combination with long-term VOC flux measurements the application of gap-filling routines is inevitable in order to replace missing data and make an important step towards a better understanding of the VOC ecosystematmosphere exchange on longer timescales.

We performed VOC flux measurements above a mountain meadow in Austria during two complete growing seasons (from snowmelt in spring to snow reestablishment in late autumn) and used this data set to test the performance of four different gap-filling routines, mean diurnal variation (MDV), mean gliding window (MGW), look-up tables (LUT) and linear interpolation (LIP), in terms of their ability to replace missing flux data in order to obtain reliable VOC sums. According to our findings the MDV routine was outstanding with regard to the minimization of the gap-filling error for both years and all quantified VOCs. The other gap-filling routines, which performed gap-filling on $24 \mathrm{~h}$ average values, introduced considerably larger uncertainties. The error which was introduced by the application of the different filling routines increased linearly with the number of data gaps. Although average VOC fluxes measured during the winter period (complete snow coverage) were close to zero, these were highly variable and the filling of the winter period resulted in considerably higher uncertainties compared to the application of gap-filling during the measurement period.

The annual patterns of the overall cumulative fluxes for the quantified VOCs showed a completely different be-
\end{abstract}

haviour in 2009, which was an exceptional year due to the occurrence of a severe hailstorm, compared to 2011. Methanol was the compound which, at $381.5 \mathrm{mg} \mathrm{C} \mathrm{m}^{-2}$ and $449.9 \mathrm{mg} \mathrm{C} \mathrm{m}^{-2}$, contributed most to the cumulative VOC carbon emissions in 2009 and 2011, respectively. In contrast to methanol emissions, however, considerable amounts of monoterpenes ( $-327.3 \mathrm{mg} \mathrm{C} \mathrm{m}^{-2}$ ) were deposited onto the mountain meadow during 2009 caused by a hailstorm. Other quantified VOCs had considerably lower influences on the annual patterns.

\section{Introduction}

The net ecosystem carbon balance (NECB) refers to the exchange (fluxes) of all forms of gaseous ( $\mathrm{FCg}$ ), solid (FCs) and liquid $(\mathrm{FCl})$ carbon $(\mathrm{C})$ through the boundaries of an ecosystem, i.e.

$\mathrm{NECB}=\mathrm{FCg}+\mathrm{FCs}+\mathrm{FCl}=\mathrm{d} C / \mathrm{d} t$,

and equates to the time-rate-of-change in ecosystem carbon pools (Chapin et al., 2006). Gaseous carbon fluxes include carbon dioxide $\left(\mathrm{CO}_{2}\right)$, methane $\left(\mathrm{CH}_{4}\right)$, carbon monoxide $(\mathrm{CO})$ and the large group of volatile organic compounds (VOCs). The exchange of solid and liquid forms of carbon involves input/export of (in)organic carbon through harvesting, fertilizer application, erosion and dissolved carbon. Typically, the NECB is evaluated at annual to decadal timescales. However, component fluxes that exhibit significant temporal variability at shorter timescales require much more frequent measurements. Gaps in these time series need to be filled before integration into the annual timescale. 
There exist a large number of different options for the imputation of these gaps (also known as gap-filling) and for $\mathrm{CO}_{2}$, which is generally thought to represent the largest component flux of the NECB, these have been evaluated extensively (Falge et al., 2001a; Moffat et al., 2007). Other gaseous carbon fluxes and especially fluxes of non-methane VOCs tend to be neglected for the NECB for several reasons. First the exchange fluxes of VOCs as trace gases are, in terms of quantity, minor compared to the carbon dioxide fluxes and are therefore thought to be much less important for the carbon balance, although many abundant VOCs contain 5-10 carbon atoms. Global inventories estimate the total emissions of VOCs into the atmosphere at $1300 \mathrm{Tg} \mathrm{yr}^{-1}$ (Goldstein and Galbally, 2007). The majority of these emissions are of biogenic origin (Laothawornkitkul et al., 2009). It is estimated that $98 \%$ of the biogenic VOC emissions can be categorized in the following five compound classes: isoprene $\left(\mathrm{C}_{5}\right)$, monoterpenes $\left(\mathrm{C}_{10}\right)$ and oxygenated VOCs like methanol, acetone, and acetaldehyde (Lathiere et al., 2006). Despite their low atmospheric concentrations (low ppb range and less), the influence of VOCs on tropospheric ozone levels and the production of secondary organic aerosols (Atkinson, 2000; Hallquist et al., 2009) is, owing to their high reactivity, significant. Aerosols and ozone have a considerable influence on the radiative forcing, but the scientific understanding of the effects is low compared to the effect of the major greenhouse gases (Forster et al., 2007). Second, flux measurements of VOCs are difficult, especially as the collectivity of VOCs is estimated to comprise at least 1000 (but probably many more) compounds (Goldstein and Galbally, 2007). Therefore, studies are usually confined to a few weeks and compounds at most and only recently have several groups started to conduct long-term flux measurements (Bamberger et al., 2010, 2011; Bouvier-Brown et al., 2012; Hörtnagl et al., 2011, 2013; Laffineur et al., 2011, 2012). Published estimates of biogenic VOC budgets thus rely heavily on modelling of the most important VOCs using simple light- and temperature-dependent algorithms (Guenther et al., 1995, 1993). As of this writing, neither closed annual time series of measured VOC fluxes exist, nor have comprehensive comparisons of gap-filling methods for VOC fluxes been conducted.

The objective of the present paper is to draw upon the experience with the imputation of annual $\mathrm{CO}_{2}$ fluxes and to systematically compare different options for filling gaps in long-term VOC flux time series. To this end we used data from a managed temperate mountain grassland in Austria, where fluxes of several VOCs, including the most prominent biogenic VOCs (acetaldehyde, acetone, isoprene, methanol and monoterpenes), have been measured over two vegetation periods by means of a proton transfer reaction mass spectrometer (PTR-MS). As a result of the gap-filling we provide annual estimates of the VOC source/sink strength and make an important step towards quantifying the NECB.

\section{Materials and methods}

\subsection{Measurement site and data acquisition}

The measurement site is located at $47^{\circ} 07^{\prime} \mathrm{N}, 11^{\circ} 19^{\prime} \mathrm{E}$ in an intensely managed mountain meadow in the Stubai Valley, Austria. The prevailing grass species in the flux footprint are graminoids and forbs. Management events of the grassland included three cuts and one fertilization (manure spreading) each year. Detailed information about the study site and the footprint is given by Bamberger et al. (2010); vegetation and soil at the study site have been described by Hammerle et al. (2008) and Wohlfahrt et al. (2008).

The VOC exchange between the vegetation and the atmosphere was measured by means of a high-sensitivity proton transfer reaction mass spectrometer (PTR-MS) using the virtual disjunct eddy covariance method (Karl et al., 2002). Continuous measurements of six different $\mathrm{m} / \mathrm{z}$ values of volatile organic compounds, methanol $(\mathrm{m} / \mathrm{z} 33)$, acetaldehyde $(m / z 45)$, acetone $(m / z 59)$, isoprene and fragments of pentenols and methylbutanals (each of the volatiles found at $m / z 69)$, the sum of monoterpenes $(m / z 137)$, and the hexenal group belonging to the green leaf volatiles $(m / z$ 99) were performed from 19 March until 11 December during 2009. Four different volatiles (methanol, acetaldehyde, acetone and the sum of monoterpenes) were quantified from 18 March 2011 until 12 December 2011. Operating conditions of the PTR-MS, which was positioned in a container next to the meadow, were set to a drift tube voltage of $600 \mathrm{~V}$ at a pressure of approximately $2.3 \mathrm{mbar}$ (Bamberger et al., 2011). Hansel et al. (1995) and Lindinger et al. (1998) give further details about the operating principle of the PTR-MS. Approximately 9 SLPM (standard liter per minute) of ambient air were pumped towards the PTR-MS through a $12 \mathrm{~m}$ long, heated $\left(35^{\circ} \mathrm{C}\right)$ Teflon ${ }^{\circledR}$ tube of $3.9 \mathrm{~mm}$ inner diameter. Mixing ratios of six/four different VOCs were measured by PTR-MS continuously at dwell times of $0.2 \mathrm{~s}$ for each $\mathrm{m} / \mathrm{z}$ value. The set of compounds was repeatedly measured every 2.3/1.6s in 2009/2011, respectively. Four step gas calibrations were automatically performed every $50 \mathrm{~h}$ diluting a standard gas (Apel Riemer Inc., United States) with VOCfree zero air. The zero air was generated by drawing ambient air through a home-built catalytic converter heated to $350^{\circ} \mathrm{C}$. VOC-free air from the catalytic converter was also used to determine the instrumental background at the end of every half-hourly measurement cycle. Methanol, acetaldehyde, acetone, isoprene and the sum of monoterpenes were included in the standard gas; $m / z 99$ (Hexenal group), however, was not included in the standard. The green leaf volatile hexenal is known to show distinct break-up patterns in the PTR-MS (Fall et al., 1999). The sensitivity of this VOC was estimated by the identification of break-up patterns and sensitivities from a liquid calibration of (E)-2-Hexenal. The ratio of the liquid calibrations of the green leaf alcohol and acetone 
was used to account for temporal variations in the sensitivities.

The 3-D wind components and the speed of sound were measured at $20 \mathrm{~Hz}$ using a sonic anemometer (R3IA, Gill Instruments, Lymington, UK) and processed on a separate PC running the EddyMeas software (O. Kolle, MPI Jena, Germany). The synchronization of the internal clocks of the VOC PC and the PC processing the sonic anemometer data was done by the network time protocol (NTP, Meinberg, Germany). The sonic anemometer was mounted at a height of $2.5 \mathrm{~m}$ above the ground and the gas inlet for the PTR-MS was located $0.1 \mathrm{~m}$ below the centre of the sonic anemometer.

\subsection{Flux calculation and quality control}

Fluxes of VOCs were calculated from turbulent departures of the vertical wind and the simultaneously measured VOC mixing ratios using the virtual disjunct eddy covariance method (Karl et al., 2002). In order to align the axes of the coordinate system to the mean streamlines of the wind a 3-D coordinate rotation was performed according to Kaimal and Finnigan (1994). The lag time for each VOC was estimated by looking for the maximum or minimum correlation coefficient between the vertical wind speed and the corresponding VOC concentration within a time window of $\pm 50 \mathrm{~s}$ and $\pm 20 \mathrm{~s}$ in 2009 and 2011, respectively. Methanol was the only compound for which a constant lag time of $1.5 \mathrm{~s}$ could be found throughout the vegetation period in both years. Therefore, if the maximum correlation between a specific compound and the corresponding vertical wind speed was not found within $3 \mathrm{~s}$ of the previously determined methanol lag, the time shift was set to the peak of the frequency distribution of the corresponding methanol lag times. The flux calculation procedure is given in more detail in Bamberger et al. (2010). Positive flux values describe the transport from the ecosystem to the atmosphere (emissions); correspondingly negative flux values describe deposition.

Flux data were rejected when (i) the third rotation angle exceeded $\pm 10^{\circ}$ (McMillen, 1988), (ii) the flux stationarity test or the deviation of the integral similarity characteristics was above $60 \%$ (Foken and Wichura, 1996) and (iii) the maximum of the footprint function (Hsieh et al., 2000) was outside the site boundaries (Novick et al., 2004). In addition, half-hourly periods with background problems like unusually high background values or a significant change in consecutive background values were removed prior to the flux calculation (Bamberger et al., 2010). During 2011 half-hourly periods with instrumental spikes originating from problems with a secondary electron multiplier were also rejected.

\subsection{Gap-filling procedures}

Half-hourly VOC flux values passing the quality control were retained, whereas flux values that did not pass were termed missing values. Data gaps with two or less hours of missing values in the time series were filled with interpolated values prior to further treatments. Afterwards, the data set was subjected to different gap-filling routines in order to replace missing data values in the series on a half-hourly or daily scale.

\subsubsection{Gap-filling on a half-hourly basis (MDV)}

With the MDV (mean diurnal variation) method missing data values were filled by calculating average diurnal cycles within a time window of \pm 8 days around the missing value. Afterwards, the missing value was replaced by the corresponding value in the diurnal cycle of the desired time period. The gliding time window of \pm 8 days around the missing value was chosen long enough to include a representative amount of data points for the averaging in order to reduce the random flux uncertainty, but short enough to respond to seasonal changes. Data gaps exceeding $75 \%$ or more of the MDV time window were observed only for one compound at the end of the measurement period when the meadow was covered by snow $(m / z 69)$. The advantage of this gap-filling method is the retention of the high time resolution of the original data series and the ability to capture the average diurnal flux pattern.

\subsubsection{Gap-filling of daily averages}

For most purposes it is easier, faster, and cost-effective (in terms of computing power) to have long-term data sets with a lower time resolution. For purposes where daily patterns are not required, gap-filling routines working on diurnal average values are of interest.

Daily average VOC fluxes were calculated from the halfhourly values for each measurement day with a data coverage exceeding $85 \%$. Days with 8 or more missing values (data coverage below $85 \%$ ) were rejected and treated as missing values for the following gap-filling routines.

\section{Gap-filling by interpolated values (LIP)}

Missing values in the daily averages of the measurement data were filled by linear interpolation (LIP) between adjacent days with available measurement values. Gaps at the beginning or end of the measurement period, when a linear interpolation was not possible, were filled by nearest-neighbour interpolation.

\section{Gap-filling by look-up tables (LUT)}

In order to create look-up tables, days were divided into combined categories of average temperature (5 classes selected in order to guarantee equally balanced number of measurement days in every class: $\leq 3{ }^{\circ} \mathrm{C}, 3-9,9-11.5$, $11.5-15$ and $\geq 15^{\circ} \mathrm{C}$ ), photosynthetic active radiation (PAR) (low $<300 \mu \mathrm{mol} \mathrm{m}{ }^{-2} \mathrm{~s}^{-1} / \mathrm{high} \geq 300 \mu \mathrm{mol} \mathrm{m}^{-2} \mathrm{~s}^{-1}$ ),

precipitation (yes/no) and green area index (GAI) 
(low $<3.5 \mathrm{~m}^{2} \mathrm{~m}^{-2} / \mathrm{high} \geq 3.5 \mathrm{~m}^{2} \mathrm{~m}^{-2}$ ). Days with snow coverage at the beginning or end of the measurement period were grouped separately, independent of other conditions. Average VOC fluxes were calculated for each category and missing values in VOC flux time series were replaced by these averages for the respective category in the lookup table (LUT). The size of the combined temperature, PAR, precipitation and GAI ranges was chosen in order to guarantee at least six to eight measurement days within each category. In cases where the number of measurement days in a special group was low and the gap-filling was not successful (category without valid VOC flux averages), categories were extended stepwise (merging of neighbouring categories with poor occupation) until a group average was found in order to guarantee a successful imputation.

\section{Gap-filling by mean values within a gliding window (MGW)}

With this method missing daily values were replaced by the running average of \pm 8 days centered on the day of the gap. The size of the time window reflects a compromise between the opposing requirements for a robust database and as few seasonal changes as possible. We also tested time windows of different sizes (e.g. \pm 16 days and \pm 30 days), but the effect of the window size on annual cumulative fluxes and the associated gap-filling errors was, with the exception of the monoterpenes, negligible. Data gaps during the first and last eight days of the measurement period were filled, averaging a fixed time window covering the first/last 17 days of measurements, respectively.

\subsubsection{Gap-filling winter period}

During the winter period, when the meadow was covered by snow, the VOC measurements were stopped and the data set thus included only 20/5 days of measurements out of 116/100 days with snow cover during 2009/2011, respectively. In order to get a complete annual time series, imputation of the winter data was essential, but none of the methods described above was well suited for these sparse data. Therefore we treated the winter period separately. For the gap-filling of the winter period we used available VOC-flux data during days with full snow cover in 2009 and 2011 and evaluated possible flux values for the corresponding winter periods by calculating (a) average values/average diurnal cycles and (b) median values/median diurnal cycles of the available days with snow cover during 2009 and 2011, respectively. These values were used to fill each winter day/half hour without corresponding measurements and to calculate the estimates for cumulative wintertime fluxes, accordingly. A third approach, leading to zero winter time fluxes, would be the padding of snow cover days with zeros, assuming that there is no exchange of volatiles between the meadow and the atmosphere when the vegetation is covered by snow.

\subsection{Error analysis}

For the error analysis of the different gap-filling procedures the original data set (with data gaps) was used as the reference. Short-term peaks in the fluxes, caused by cutting and subsequent drying of the grass or fertilization (Brilli et al., 2012; Ruuskanen et al., 2011), were additionally removed from the data set. In order to fill the missing values in the sample time series for the different VOCs we extracted random days using bootstrapping within a time window of \pm 20 days around the data gap and used the corresponding flux value to fill the data gap. In case the bootstrapped day was also a day with missing flux data the procedure was repeated until a day with a valid flux value was found. On a halfhourly scale the bootstrapping was performed in the same way with respect to the time of day. The resulting (gap-free) time series was used as a reference time series for the estimation of errors due to the gap-filling. Gaps were simulated by removing data from the reference time series at random places (preserving the size and composition of the original data gaps) and the resulting intermittent data series (with artificial gaps) was patched by the four gap-filling routines mentioned above.

This procedure was repeated 500 times, leading to 500 different reference and gap-filled time series. For each of the 500 samples, cumulative fluxes for both the reference and gap-filled time series were calculated. The difference between the cumulative fluxes of reference and the gap-filled time series was calculated for each of the 500 steps and reflects the error introduced by the gap-filling. Three metrics were calculated to quantify this error: (1) the mean error, reflecting any systematic bias; (2) the root mean square error; and (3) the maximum error.

For the winter period the error regarding the gap-filling was estimated separately using an error propagation of the standard deviation $/ 75 \%$ percentiles of the available snow data accounting for the gap-filled period. In addition, maximal errors, which are hypothetically introduced by gapfilling of the winter data, were calculated by filling data gaps during snow cover with maximal/minimal values measured on days with snow cover.

\section{Results and discussion}

\subsection{VOC flux data}

Fluxes of six different $\mathrm{m} / z$ values corresponding to specific VOCs $-m / z 33$ (methanol), $m / z 45$ (acetaldehyde), $\mathrm{m} / z 59$ (acetone/propanal), $\mathrm{m} / \mathrm{z} 99$ (e.g. hexenals), $\mathrm{m} / \mathrm{z}$ 137 (sum of monoterpenes, MTs), and $m / z 69$ representing isoprene and especially during management actions fragments of methylbutanals and pentenols (Fall et al., 2001; Karl et al., 2001) were measured above the mountain grassland during the time period from 18 March 2009 until 

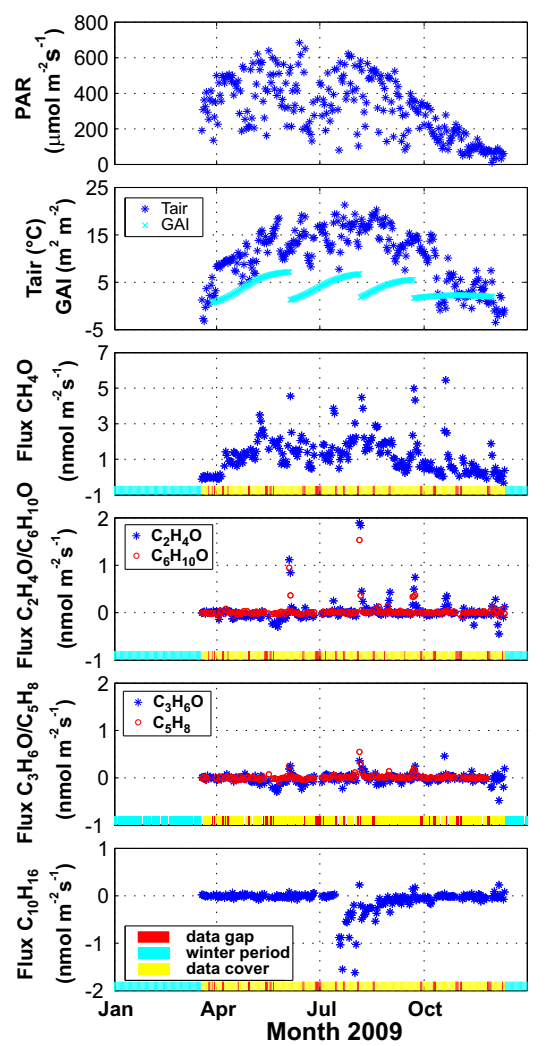
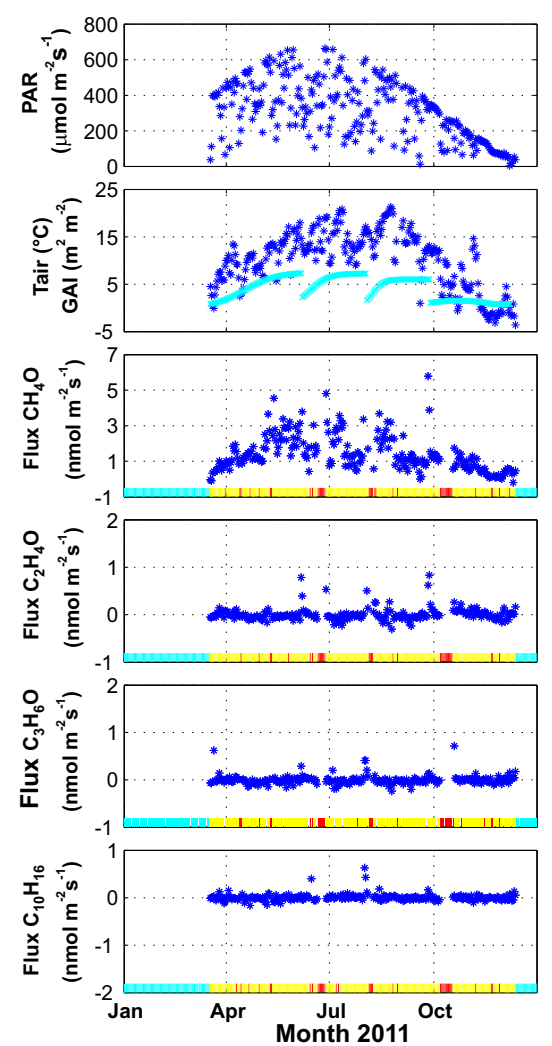
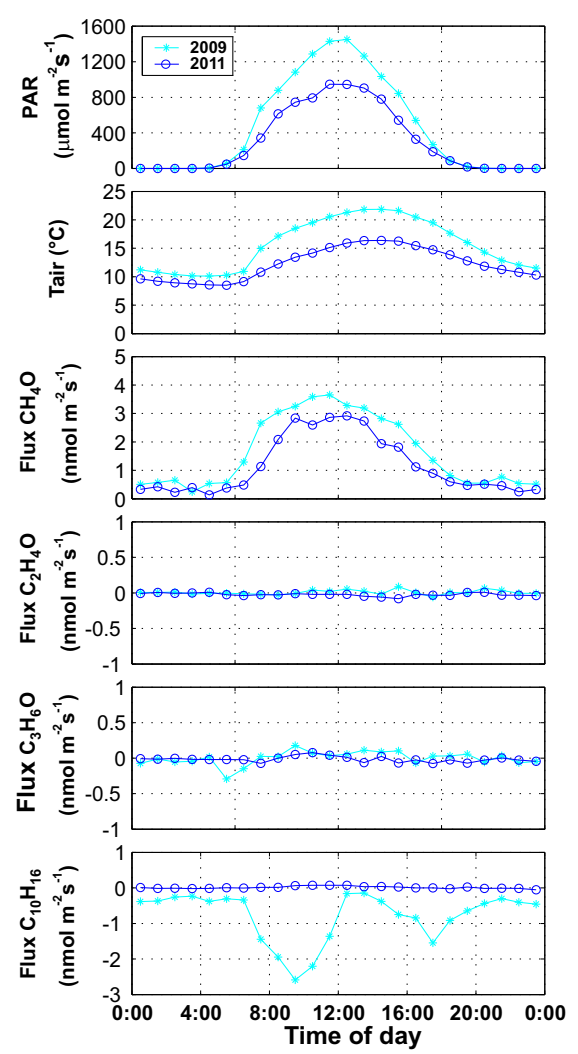

Fig. 1. Time series of daily averages of photosynthetically active radiation (PAR), air temperature (Tair), the green area index (GAI) and VOC fluxes for the years 2009 (left column) and 2011 (centre column) and average diurnal cycles for the same variables and a selected time period (18 July-1 August) in the summers of 2009 and 2011 (right column). The winter period (cyan), data gaps (red) and data cover (yellow) for the different VOCs are earmarked as horizontal bars at the bottom of each time series.

11 December 2009, including 20 days with snow cover. During the 267 days of half-hourly flux measurements data gaps accumulated to a total of 11.1, 11.3, 11.6, 11.2, 11.7 and $16.7 \%$ for $m / z 33, m / z 45, m / z 59, m / z 99, m / z 137$ and $m / z 69$, respectively. During 2011 only fluxes of methanol, acetaldehyde, acetone and monoterpenes were quantified for the time period between 17 March 2011 and 12 December 2011, including only 5 days of snow cover. The percentage of data gaps on a half-hourly scale was quite comparable to the year 2009, at $11.2 \%$ (methanol), $10.9 \%$ (acetaldehyde), $10.9 \%$ (acetone) and $11.2 \%$ (monoterpenes).

Due to the restriction regarding the calculation of diurnal averages (see above), the procedures applied on a daily scale tended to reject on average 6 and $3 \%$ more data compared to the gap-filling procedure on a half-hourly scale for the years 2009 and 2011, respectively. Consequently, on a daily scale $17.2 \%(\mathrm{~m} / \mathrm{z} 33), 18.3 \%(\mathrm{~m} / \mathrm{z} 45), 18.3 \%(\mathrm{~m} / \mathrm{z} 59), 17.2 \%$ $(\mathrm{m} / \mathrm{z} 99), 17.2 \%(\mathrm{~m} / \mathrm{z} 137)$ and $22.8 \%(\mathrm{~m} / \mathrm{z} 69)$ of the data were treated as missing values in 2009 . The number of rejected data for the daily scale flux calculation were reduced in 2011, when the data gaps accounted only for 14.8, 12.6, 14.4 and $14.1 \%$ (for methanol, acetaldehyde, acetone, and monoterpenes) as a consequence of fewer, but longer lasting data gaps.

Figure 1 gives an overview of the environmental conditions, plant canopy development and the measured fluxes of volatiles above the grassland site during the years 2009 and 2011. Methanol fluxes exhibited a clear diurnal cycle throughout the whole growing season, reaching peak values up to $9.2 \mathrm{nmol} \mathrm{m}^{-2} \mathrm{~s}^{-1}$ during midday and close to zero fluxes during night-time in the absence of sunlight (Hörtnagl et al., 2011). In contrast to 2011, monoterpene fluxes in 2009 showed a strong tendency towards deposition (negative values) - a consequence of a severe hailstorm in June 2009. The hailstorm induced high ambient concentrations of monoterpenes probably caused by elevated terpene emissions from damaged coniferous trees which grow outside of the flux footprint on the valley slopes (Bamberger et al., 2011). The substantial increase in monoterpene emissions from coniferous trees as a consequence of a hailstorm was verified in a separate study (Kaser et al., 2013). Compounds other than methanol or monoterpenes showed considerably lower, frequently close-to-zero fluxes without clear diurnal patterns under regular growing conditions. During cutting and fertilization of the meadow VOC emissions showed considerably 
Table 1. Overall cumulative flux (averaged over all methods), mean error (systematic deviation in a positive or negative direction), root mean square error and maximal error (maximal deviation from reference) calculated for the four different gap-filling routines (mean diurnal variation, look-up tables, mean gliding window, linear interpolation) which were applied to the measured VOC data series for the years 2009 and 2011 (cutting times were previously excluded for the error simulation)

\begin{tabular}{|c|c|c|c|c|c|c|c|c|c|}
\hline \multicolumn{3}{|c|}{ Error gap-filling } & \multirow{2}{*}{$\begin{array}{r}m / z 33 \\
385.7\end{array}$} & \multirow{2}{*}{$\begin{array}{r}m / z 45 \\
8.2\end{array}$} & \multirow{2}{*}{$\begin{array}{r}m / z 59 \\
-12.7\end{array}$} & \multirow{2}{*}{$\begin{array}{r}m / z 99 \\
24.2\end{array}$} & \multirow{2}{*}{$\begin{array}{r}m / z 137 \\
-320.7\end{array}$} & \multirow{2}{*}{$\frac{m / z 69}{14.3}$} & \multirow{2}{*}{$\begin{array}{r}\text { VOC } \\
98.9\end{array}$} \\
\hline 2009 & Cumulative flux $\left(\mathrm{mg} \mathrm{C} \mathrm{m}^{-2}\right)$ & & & & & & & & \\
\hline & Mean error $\left(\mathrm{mg} \mathrm{C} \mathrm{m}^{-2}\right)$ & MDV & 0.1 & 0.0 & 0.1 & 0.0 & 1.8 & -0.1 & -1.9 \\
\hline & & LUT & 0.2 & 0.0 & 0.0 & 0.0 & -0.3 & -0.1 & -0.2 \\
\hline & & MGW & -0.1 & 0.2 & 0.3 & 0.1 & -1.8 & -0.1 & -1.4 \\
\hline & & LIP & 1.2 & 0.0 & 0.0 & -0.2 & -1.0 & -0.3 & -0.3 \\
\hline & Root mean square error $\left(\mathrm{mg} \mathrm{C} \mathrm{m}^{-2}\right)$ & MDV & 3.3 & 0.9 & 1.2 & 0.9 & 16.5 & 1.2 & 24.0 \\
\hline & & LUT & 7.6 & 2.5 & 2.9 & 1.8 & 39.6 & 2.1 & 56.5 \\
\hline & & MGW & 8.0 & 2.0 & 2.7 & 1.6 & 33.7 & 1.7 & 49.7 \\
\hline & & LIP & 8.6 & 2.6 & 3.4 & 2.2 & 40.8 & 2.2 & 59.8 \\
\hline & Maximum error $\left(\mathrm{mg} \mathrm{C} \mathrm{m}^{-2}\right)$ & MDV & 9.0 & 2.6 & 3.2 & 2.3 & 82.5 & 3.3 & 102.9 \\
\hline & & LUT & 19.8 & 7.0 & 9.3 & 5.9 & 121.6 & 7.2 & 170.8 \\
\hline & & MGW & 29.7 & 6.4 & 8.2 & 5.5 & 105.3 & 7.4 & 162.5 \\
\hline & & LIP & 43.2 & 11.3 & 11.7 & 7.1 & 252.8 & 8.1 & 334.2 \\
\hline \multirow[t]{13}{*}{2011} & Cumulative flux $\left(\mathrm{mg} \mathrm{C} \mathrm{m}^{-2}\right)$ & & 450.0 & 14.2 & 3.4 & - & 9.3 & - & 476.8 \\
\hline & Mean error $\left(\mathrm{mg} \mathrm{C} \mathrm{m}^{-2}\right)$ & MDV & 0.3 & 0.0 & 0.1 & - & 0.0 & - & 0.4 \\
\hline & & LUT & 0.0 & -0.1 & 0.0 & - & 0.1 & - & 0.0 \\
\hline & & MGW & 0.4 & 0.0 & 0.0 & - & 0.4 & - & 0.8 \\
\hline & & LIP & 0.3 & 0.0 & 0.0 & - & -0.2 & - & 0.1 \\
\hline & Root mean square error $\left(\mathrm{mg} \mathrm{C} \mathrm{m}^{-2}\right)$ & MDV & 6.3 & 2.1 & 1.6 & - & 3.3 & - & 13.3 \\
\hline & & LUT & 11.3 & 2.1 & 2.6 & - & 5.1 & - & 21.1 \\
\hline & & MGW & 11.0 & 2.3 & 2.6 & - & 5.2 & - & 21.1 \\
\hline & & LIP & 13.1 & 3.3 & 4.3 & - & 7.8 & - & 28.5 \\
\hline & Maximum error $\left(\mathrm{mg} \mathrm{C} \mathrm{m}^{-2}\right)$ & MDV & 23.3 & 6.8 & 4.6 & - & 12.4 & - & 47.1 \\
\hline & & LUT & 39.0 & 5.8 & 9.4 & - & 14.0 & - & 68.2 \\
\hline & & MGW & 40.6 & 8.2 & 14.5 & - & 18.7 & - & 82.0 \\
\hline & & LIP & 56.7 & 12.7 & 23.9 & - & 28.9 & - & 122.2 \\
\hline
\end{tabular}

higher peak values than during undisturbed conditions (Brilli et al., 2012; Ruuskanen et al., 2011), especially evident for compounds which normally exhibit less prominent emission patterns (compare Fig. 1).

\subsection{Gap-filling and error assessment}

\subsubsection{Variation of VOC budgets received with different gap-filling routines}

Cumulative carbon fluxes of the gap-filled time series were calculated based on the four different methods and the set of different VOCs. A comparison between the cumulative fluxes of different VOCs, received as a result of the application of different gap-filling methods, showed that all methods yielded similar cumulative carbon fluxes for all VOCs in 2009 and 2011 (Fig. 2). The lowest variability between the cumulative carbon fluxes, received by the application of different gap-filling methods to the VOC raw data, was observed for methanol. Depending on the gap-filling method which was applied, cumulative methanol fluxes ranged between $376.0 \mathrm{mg} \mathrm{C} \mathrm{m}^{-2}$ and $401.5 \mathrm{mg} \mathrm{C} \mathrm{m}^{-2}$ in 2009 , and be- tween $447.5 \mathrm{mg} \mathrm{C} \mathrm{m}^{-2}$ and $453.6 \mathrm{mg} \mathrm{C} \mathrm{m}^{-2}$ in 2011 . The variation between these values was only 6.6 and $1.4 \%$ of the methanol average (over all methods) cumulative carbon flux for 2009 and 2011, respectively. Cumulative fluxes for sum of monoterpenes, for example, at $9.1 \%$ (of the total MT fluxes), showed a higher variability $\left(-329.3 \mathrm{mg} \mathrm{C} \mathrm{m}^{-2}\right.$ to $-300.0 \mathrm{mg} \mathrm{C} \mathrm{m}^{-2}$ ) for the different gap-filling methods in 2009. Fluxes of the other compounds were considerably lower compared to methanol and monoterpenes (only in 2009) and their contribution to the variability of overall VOC cumulative fluxes was less important. Wintertime fluxes, which are shown separately in Fig. 2, are included in these numbers, but they were generally low and had a minor influence on the yearly values (compare Fig. 2).

\subsubsection{Errors due to gap-filling}

Table 1 shows the errors introduced by the gap-filling using the four different filling methods. Regarding the performance of the individual filling methods, the MDV method yielded clearly the most accurate results for both years and all investigated VOCs. The performance of the LUT and the 


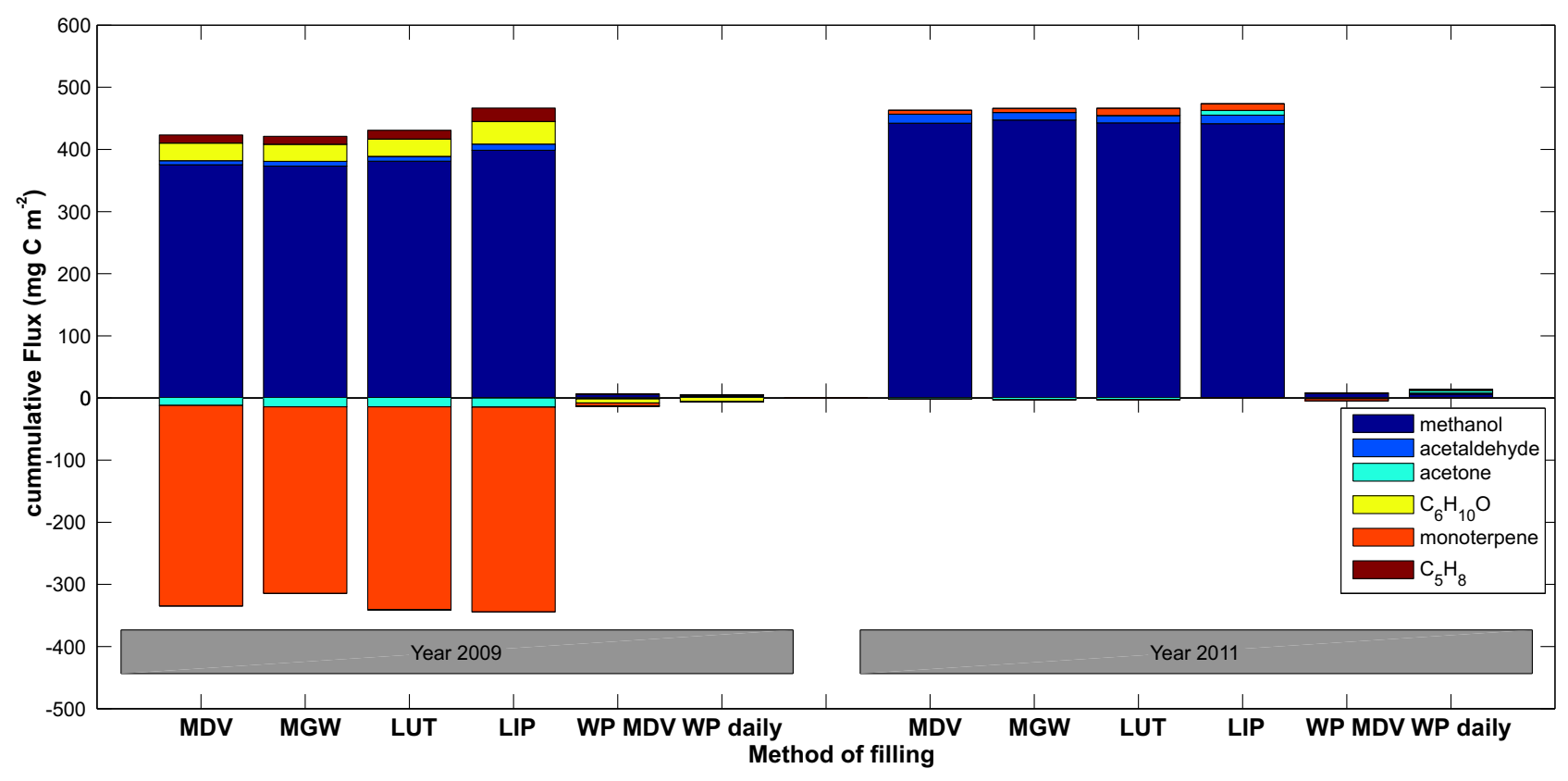

Fig. 2. Bar graph of the cumulative carbon fluxes of the different VOCs (methanol (dark blue), acetaldehyde (blue), acetone (cyan), $m / z$ 99 (yellow), monoterpenes (red) and $m / z 69$ (brown)) obtained by application of the four different gap-filling methods (MDV, MGW, LUT, LIP) for the years 2009 and 2011. The cumulative fluxes for the winter period calculated after gap-filling the complete number of missing winter measurement days on a half-hourly basis using median diurnal cycles (WP MDV) and on a daily basis using median daily values (WP daily), which were obtained from the measurements during days with snow cover (2009 and 2011), are shown as additional information.

MGW methods was quite similar compared to each other, with a small advantage of the LUT over the MGW in 2009 for methanol, but a disadvantage for all other measured volatiles and an overall performance which was better for the MGW routine. In 2011 the overall performance for both routines was quite balanced. The linear interpolation resulted in the highest root mean square errors and maximum errors overall and for each single VOC separately. As a compound with a clear diurnal cycle the cumulative sum of methanol was captured with a root mean square error of $0.9 / 1.4 \%$ and a maximum error of $2.3 / 5.2 \%$ (with respect to the cumulative methanol flux) using the best gap-filling routine for the years 2009 and 2011, respectively. The other filling routines introduced root mean square errors of around $2 \%$ for 2009 and between 2.4 and $2.9 \%$ for 2011. Monoterpene cumulative carbon fluxes resulted in a similar absolute cumulative flux compared to methanol, but were quantified with considerably higher root mean square errors (best method $5.1 \%$ and other methods between 10.5 and $12.7 \%$, and maximum errors between 25.7 and $78.8 \%$ ). This was due to the fact that the monoterpene deposition fluxes showed a rapidly changing behaviour with partially high deposition fluxes (close to the hail-event), which were independent of any meteorological parameters and did not follow a regular daily pattern (Bamberger et al., 2011). The maximum errors represent the worst case of the concentration of data gaps around the date of the hailstorm and are, with errors of $83 \mathrm{mg} \mathrm{C} \mathrm{m}^{-2}$ and
$105 \mathrm{mg} \mathrm{C} \mathrm{m}^{-2}$, lowest for the MDV and MGW methods. In contrast, the gap-filling by linear interpolation introduced errors up to $253 \mathrm{mg} \mathrm{C} \mathrm{m}^{-2}$. However, events which cause flux patterns and gap-filling errors comparable to the monoterpene deposition behaviour in 2009 are certainly an exceptional case.

Although the percentage of missing data in 2011 was equal to or, on a daily timescale, even lower than during 2009, the composition of gaps was different, with a tendency towards data gaps spanning several days in 2011 . The lower errors for the individual VOCs in 2009 show that the filling of several shorter gaps (with a larger number of measurements in between) introduces considerably lower errors than the filling of the same percentage of longer gaps.

However, the influence of the monoterpene deposition in 2009 did result in a considerably lower net VOC carbon emission in 2009 compared to 2011. As a consequence, both the absolute and relative error for the sum of the VOCs, which was introduced by the gap-filling, was lower in 2011 (root mean square errors between 2.8 and $6.0 \%$ ) compared to 2009 (24.2-60.7 \%).

Results further showed that accounting for diurnal cycles during gap-filling reduced the uncertainties which were introduced by the data padding considerably. This was even true for VOCs, which showed no distinct diurnal course throughout the year. This is most likely due to the variable position and limited size of the time window used 
Table 2. Example of how mean, root mean square and maximal errors introduced by the application of the four gap-filling routines change if management events on the meadow were included for the error simulation in 2009.

\begin{tabular}{|c|c|c|c|c|c|c|c|c|c|}
\hline \multicolumn{3}{|c|}{ Error if gaps during cutting are filled } & \multirow{2}{*}{$\begin{array}{r}m / z 33 \\
4.3\end{array}$} & \multirow{2}{*}{$\begin{array}{r}m / z 45 \\
-0.1\end{array}$} & \multirow{2}{*}{$\begin{array}{r}m / z 59 \\
-0.3\end{array}$} & \multirow{2}{*}{$\begin{array}{r}m / z 99 \\
0.0\end{array}$} & \multirow{2}{*}{$\begin{array}{r}m / z 137 \\
-6.6\end{array}$} & \multirow{2}{*}{$\begin{array}{r}m / z 69 \\
0.2\end{array}$} & \multirow{2}{*}{$\begin{array}{r}\text { VOC } \\
-2.5\end{array}$} \\
\hline 2009 & Mean error $\left(\mathrm{mg} \mathrm{C} \mathrm{m}^{-2}\right)$ & MDV & & & & & & & \\
\hline & & LUT & 2.5 & -1.1 & 1.6 & -0.4 & 10.0 & -0.6 & 12.0 \\
\hline & & MGW & -0.7 & 0.1 & 0.1 & 0.1 & -0.3 & 0.3 & -0.5 \\
\hline & & LIP & -0.1 & 0.2 & -0.1 & 0.4 & -0.8 & -0.1 & -0.5 \\
\hline & Root mean square error $\left(\mathrm{mg} \mathrm{C} \mathrm{m}^{-2}\right)$ & MDV & 11.7 & 2.6 & 1.6 & 4.6 & 17.1 & 3.0 & 40.6 \\
\hline & & LUT & 34.0 & 9.6 & 5.4 & 14.5 & 56.9 & 6.5 & 126.9 \\
\hline & & MGW & 24.0 & 6.1 & 3.2 & 9.4 & 33.1 & 4.8 & 80.6 \\
\hline & & LIP & 26.2 & 6.3 & 3.6 & 11.7 & 42.8 & 5.3 & 95.9 \\
\hline & Maximum error $\left(\mathrm{mg} \mathrm{C} \mathrm{m}^{-2}\right)$ & MDV & 39.7 & 11.3 & 6.3 & 20.3 & 71.3 & 15.1 & 164.0 \\
\hline & & LUT & 175.4 & 55.0 & 22.7 & 86.8 & 294.5 & 48.6 & 683.0 \\
\hline & & MGW & 88.0 & 23.0 & 9.7 & 26.2 & 116.4 & 20.4 & 283.7 \\
\hline & & LIP & 123.4 & 27.3 & 11.7 & 78.3 & 260.7 & 23.5 & 524.9 \\
\hline
\end{tabular}

for averaging. With these restrictions it was still possible to reconstruct diurnal patterns, which were only present for a certain time frame, quite well. The performance of gap-filling on a daily scale was clearly inferior. Integrating look-up tables which calculate fluxes according to ambient conditions and growing state of the vegetation did not show a clear advantage for all VOCs over usual gliding window averaging and even a clear disadvantage in the case of rapidly changing flux patterns (e.g. for monoterpene deposition in 2009). While during 2009 we saw slightly lower errors with the application of the LUT routine (compared to other daily methods) for methanol, which is known to correlate with photosynthetically active radiation and temperature at this measurement site (Hörtnagl et al., 2011), this was not visible for the overall VOC balance or for cumulative methanol fluxes in 2011.

\subsubsection{Effect of gap-filling during management events}

The time series of measurements exhibited no extended ( $>2 \mathrm{~h}$ ) data gaps during management actions of the grassland (cutting and fertilization); however, these periods were excluded from the gap-filling simulation for Table 1 . The effect of gap-filling during such management events, which have a large influence on the magnitude and multitude of emitted VOCs (Brilli et al., 2012; Ruuskanen et al., 2011; Hörtnagl et al., 2013), was therefore simulated for the year 2009 as an example and is presented in Table 2. In this case, the root mean square errors increased approximately by a factor of three for methanol, acetaldehyde, and $m / z 69$, volatiles which are highly influenced by cutting, and even by a factor of five for the hexenal group $\mathrm{C}_{6} \mathrm{H}_{10} \mathrm{O}$ (measured on $\mathrm{m} / \mathrm{z}$ 99), which is one characteristic compound class for cutting. Root mean square errors for monoterpenes and $\mathrm{m} / z 59$ (tentatively assigned to acetone), both compounds, which are less sensitive to cutting events, remained almost unchanged or showed only a small increase. Generally, root mean square errors from the look-up-table routine increased considerably more (compared to the example without data gaps during management actions) than for other gap-filling routines, especially for monoterpenes and acetone. The results of Table 2 suggest that gap-filling for cutting days should be performed with special care. The filling of those gaps would probably introduce lower uncertainties if the missing data replacement would rely on information from previous cuts at the same measurement site.

\subsubsection{Gap-filling for the winter period}

The previous paragraphs as well as Table 1 and Table 2 describe the errors which were introduced by gap-filling of values during the growing period of the vegetation. Winter fluxes over the grassland were considered to be negligible a priori because the vegetation is usually covered by snow. Therefore measurements were conducted mainly during the snow-free time of the year, covering only some days of complete snow cover (20 days in the year 2009 and only five days during 2011). There is a considerably higher amount of winter days without measurement data and none of the previously applied gap-filling routines seemed to be suitable as a gap-filling routine for the winter data. Therefore we applied different filling routines for the winter data, which were based on the available days with snow cover in the winter period as described in Sect. 2.3.3. Due to the low amount of measurement days with snow cover in 2011 the filling during this year was performed using the mean/median values for the complete data series available during snow measurements (including 2009 and 2011 winter data). Compared to the year 2011, in 2009 two additional VOCs were quantified and the number of measurements during snow cover was higher. Therefore we used only the mean/median winter measurements of 2009 for the padding of the winter period of 2009. Table 3 shows the results for the calculated wintertime cumulative fluxes (after gap-filling the days 
Table 3. Cumulative VOC fluxes for the winter period not covered by measurements (96 days in 2009 and 95 days in 2011 ) including corresponding errors calculated on a diurnal/half-hourly basis for the years 2009 and 2011 . The winter fluxes were gap-filled using mean/mean diurnal cycles and median/median diurnal cycles (calculated from measurements during snow-lying days). In addition the estimated values for the maximum and minimum cumulative fluxes for the winter data are stated.

\begin{tabular}{|c|c|c|c|c|c|c|c|c|c|}
\hline \multicolumn{3}{|c|}{$\begin{array}{l}\text { Cumulative winter flux estimates } \\
\text { including possible errors }\end{array}$} & \multirow{2}{*}{$\begin{array}{r}m / z 33 \\
5.7\end{array}$} & \multirow{2}{*}{$\begin{array}{r}m / z 45 \\
-3.9\end{array}$} & \multirow{2}{*}{$\begin{array}{r}m / z 59 \\
-8.6\end{array}$} & \multirow{2}{*}{$\begin{array}{r}m / z 99 \\
-1.0\end{array}$} & \multirow{2}{*}{$\begin{array}{r}m / z 137 \\
5.3\end{array}$} & \multirow{2}{*}{$\begin{array}{r}m / z 69 \\
-2.8\end{array}$} & \multirow{2}{*}{$\begin{array}{l}\text { VOC } \\
-5.7\end{array}$} \\
\hline 2009 & Mean cum. flux & $30 \mathrm{~min}$ & & & & & & & \\
\hline \multirow{11}{*}{ (96 days) } & $\left(\mathrm{mg} \mathrm{Cm}^{-2}\right)$ & Daily & 6.4 & -3.4 & -6.6 & -0.1 & 13.4 & -2.0 & 7.7 \\
\hline & \multirow{2}{*}{$\begin{array}{l}\text { Error mean cum. flux } \\
\left(\mathrm{mg} \mathrm{C} \mathrm{m}^{-2}\right)\end{array}$} & $30 \mathrm{~min}$ & 108.6 & 104.5 & 112.5 & 113.4 & 248.7 & 37.2 & 760.6 \\
\hline & & Daily & 16.4 & 23.9 & 31.9 & 16.1 & 55.5 & 9.3 & 158.1 \\
\hline & \multirow{2}{*}{$\begin{array}{l}\text { Median cum. flux } \\
\left(\mathrm{mgC} \mathrm{m}^{-2}\right)\end{array}$} & $30 \mathrm{~min}$ & 6.3 & -1.1 & -0.4 & -6.4 & -4.6 & -1.4 & -9.6 \\
\hline & & Daily & 2.8 & 0.7 & 1.6 & -5.7 & 0.3 & -1.0 & -3.1 \\
\hline & \multirow{2}{*}{$\begin{array}{l}\text { 75th percentile cum. flux } \\
\left(\mathrm{mg} \mathrm{C} \mathrm{m}^{-2}\right)\end{array}$} & $30 \mathrm{~min}$ & 33.9 & 26.5 & 34.7 & 46.9 & 96.3 & 19.2 & 272.4 \\
\hline & & Daily & 12.0 & 3.4 & 4.8 & 7.8 & 15.4 & 7.0 & 52.9 \\
\hline & \multirow{2}{*}{$\begin{array}{l}\text { Maximum cum. flux } \\
\left(\mathrm{mg} \mathrm{C} \mathrm{m}^{-2}\right)\end{array}$} & $30 \mathrm{~min}$ & 244.5 & 214.9 & 206.4 & 288.5 & 540.9 & 49.0 & 1635.2 \\
\hline & & daily & 52.7 & 56.0 & 58.2 & 46.4 & 231.0 & 10.5 & 469.5 \\
\hline & \multirow{2}{*}{$\begin{array}{l}\text { Minimum cum. flux } \\
\left(\mathrm{mg} \mathrm{C} \mathrm{m}^{-2}\right)\end{array}$} & $30 \mathrm{~min}$ & -255.8 & -287.7 & -293.8 & -208.8 & -501.4 & -57.7 & -1671.3 \\
\hline & & Daily & -34.6 & -90.8 & -145.0 & -42.0 & -73.6 & -21.6 & -420.9 \\
\hline \multirow{12}{*}{$\begin{array}{l}2011 \\
\text { (95 days) }\end{array}$} & \multirow{4}{*}{$\begin{array}{l}\text { Mean cum. flux } \\
\left(\mathrm{mg} \mathrm{C} \mathrm{m}^{-2}\right) \\
\text { Error mean cum. flux } \\
\left(\mathrm{mg} \mathrm{C} \mathrm{m}^{-2}\right)\end{array}$} & $30 \mathrm{~min}$ & 9.6 & -1.9 & -3.8 & - & 6.8 & - & 10.7 \\
\hline & & Daily & 10.8 & -0.6 & -1.2 & - & 14.5 & - & 23.5 \\
\hline & & $30 \mathrm{~min}$ & 88.8 & 79.5 & 85.1 & - & 193.1 & - & 446.4 \\
\hline & & Daily & 23.2 & 27.0 & 37.2 & - & 68.8 & - & 156.2 \\
\hline & \multirow{2}{*}{$\begin{array}{l}\text { Median cum. flux } \\
\left(\mathrm{mgC}^{-2}\right)\end{array}$} & $30 \mathrm{~min}$ & 7.7 & -1.1 & 0.4 & - & -3.6 & - & 3.4 \\
\hline & & Daily & 6.2 & 1.8 & 4.4 & - & 1.9 & - & 14.3 \\
\hline & \multirow{2}{*}{$\begin{array}{l}\text { 75th percentile cum. flux } \\
\left(\mathrm{mg} \mathrm{C} \mathrm{m}^{-2}\right)\end{array}$} & $30 \mathrm{~min}$ & 28.0 & 21.5 & 25.5 & - & 73.5 & - & 148.6 \\
\hline & & Daily & 24.8 & 3.3 & 8.1 & - & 18.2 & - & 54.5 \\
\hline & \multirow{2}{*}{$\begin{array}{l}\text { Maximum cum. flux } \\
\left(\mathrm{mg} \mathrm{C} \mathrm{m}^{-2}\right)\end{array}$} & $30 \mathrm{~min}$ & 339.8 & 302.9 & 273.3 & - & 777.4 & - & 1693.3 \\
\hline & & Daily & 51.6 & 54.9 & 57.0 & - & 226.3 & - & 389.8 \\
\hline & \multirow{2}{*}{$\begin{array}{l}\text { Minimum cum. flux } \\
\left(\mathrm{mg} \mathrm{C} \mathrm{m}^{-2}\right)\end{array}$} & $30 \mathrm{~min}$ & -354.0 & -373.5 & -367.8 & - & -653.4 & - & -1748.7 \\
\hline & & Daily & -33.9 & -89.0 & -142.0 & - & -72.1 & - & -337.0 \\
\hline
\end{tabular}

without measurements) and corresponding errors based on two different approaches for the half-hourly and daily values: first the filling of daily values by average daily fluxes and the filling of half hourly fluxes by average diurnal patterns measured within the snow period and second the filling of daily fluxes by median daily fluxes and half hourly fluxes by median diurnal cycles measured within the snow period. Derived wintertime cumulative fluxes are generally low compared to seasonal fluxes, but the errors which are possibly introduced by a filling of the whole winter period are much higher compared to the errors introduced by a filling of data gaps during the growing season.

Up to now little has been known about VOC fluxes during wintertime and most VOC flux measurements are conducted during short-term campaigns from several weeks up to some months during the vegetation period (Brunner et al., 2007; Karl et al., 2003, 2004). Longer campaigns are rare and usually measurements over multiple years are interrupted during the winter period as well (Bamberger et al., 2011; BouvierBrown et al., 2012; Hörtnagl et al., 2011; Laffineur et al., 2012). Although our winter data estimates suggested VOC fluxes to be very low compared to the growing period, these revealed as well that there is a considerable variability in the data, which makes an exact quantification of the wintertime fluxes difficult. Therefore the trend should go towards VOC measurements covering the complete annual cycle in order to constrain uncertainties during wintertime.

\subsection{Effects of gap percentage}

The error which is possibly introduced by a gap-filling of a given amount of data gaps in a data series was extensively discussed in Sect. 3.2. This section deals with the effect of an increase/a decrease in data gaps on the error regarding the annual cumulative carbon sum for the different VOCs. Figure 3 shows the change of the root mean square error with varying data gap percentages (with respect to the total number of measurements) for the four different gap-filling methods (upper panels). For each gap-filling method the root mean square error increased approximately linearly, with the percentage of data gaps exhibiting different slopes for different VOCs and different filling methods. The growth of the mean error (blue line), root mean square error (grey bar restricted by red lines), and maximal errors (grey lines) with an 

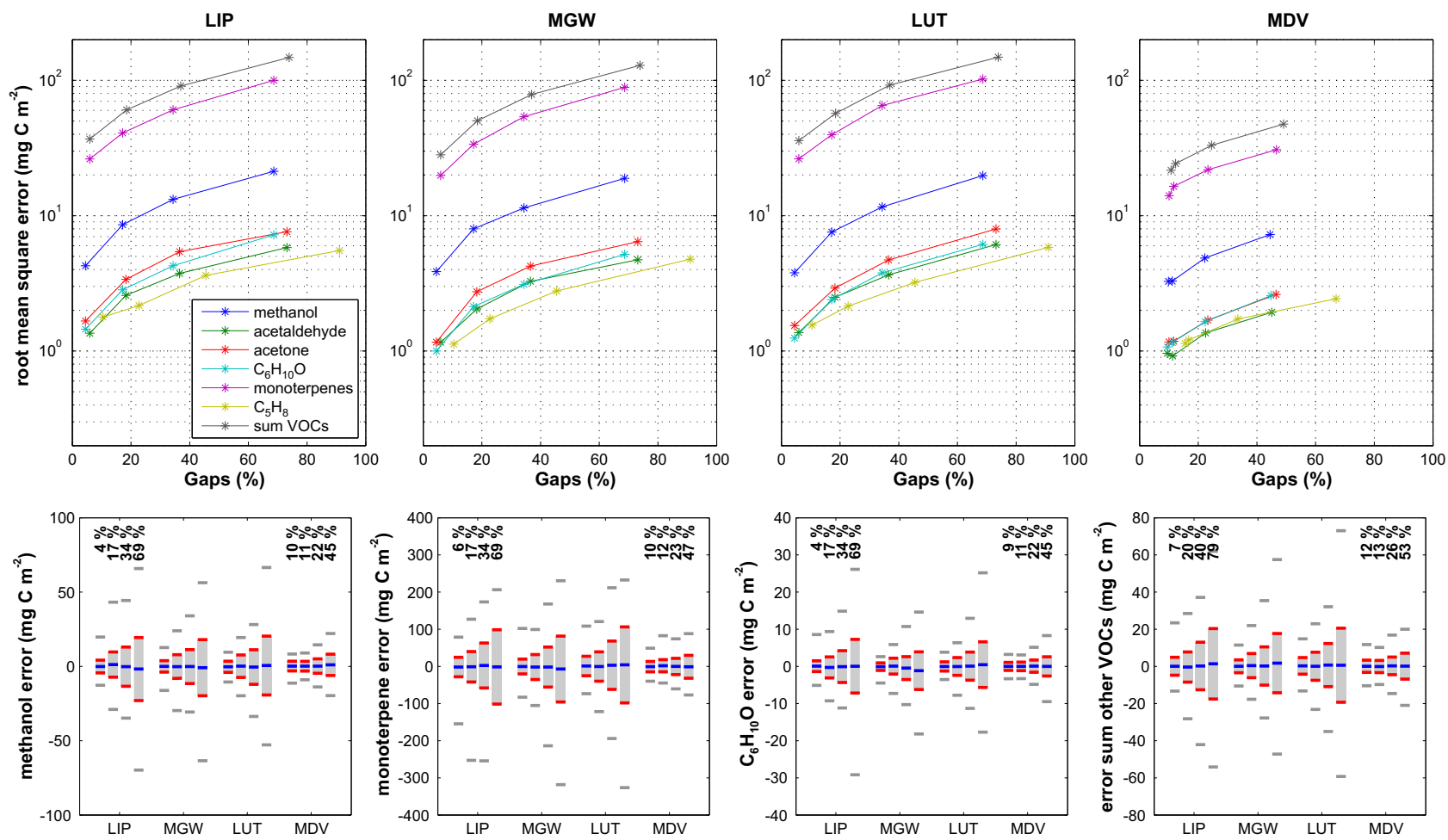

Fig. 3. Increase in root mean square errors introduced by gap-filling using the four different methods with an increasing number of gaps in the data series of quantified VOC fluxes (upper panels). Complete error statistics including mean error (blue horizontal line), ranges of root mean square errors (grey bars limited by red horizontal lines) and maximal (grey horizontal lines) errors for methanol $(\mathrm{m} / z$ 33), monoterpenes $\left(\mathrm{m} / z\right.$ 137), $\mathrm{C}_{6} \mathrm{H}_{10} \mathrm{O}(\mathrm{m} / z$ 99) and the sum of other quantified VOCs (lower panels). All figures are exemplarily shown for the year 2009 only. The percentages in the lower panels refer to the total percentage of artificially introduced and filled data gaps used for the error simulation.

increasing number of data gaps for the single VOCs is shown compressed in the lower panels of Fig. 3. Independent of the percentage of data gaps, the mean diurnal variation method (MDV) introduces the lowest errors for all VOCs.

It has become common to measure vegetation fluxes of $\mathrm{CO}_{2}$ and $\mathrm{H}_{2} \mathrm{O}$ continuously across an extended network of measurement stations all over the world (FLUXNET). Consequently the utilization of gap-filling routines to replace missing values is quite common and several tools have been tested with regard to their performance above different ecosystems (Falge et al., 2001a, b; Moffat et al., 2007; Reichstein et al., 2005). Recently, the performance of gapfilling routines was also tested for other greenhouse gas flux data like nitrous oxide $\left(\mathrm{N}_{2} \mathrm{O}\right)$ (Mishurov and Kiely, 2011) or methane $\left(\mathrm{CH}_{4}\right)$ (Dengel et al., 2013). Due to the diversity of driving factors for the fluxes of different VOCs (Brilli et al., 2012; Ruuskanen et al., 2011), it was difficult to devise a method which was valid for all VOCs, which limited the choice of methods. A similar problem was observed by Mishurov and Kiely (2011) for $\mathrm{N}_{2} \mathrm{O}$ fluxes. Mishurov and Kiely (2011) considered a look-up-table approach on a yearly scale to be the most successful method. Although we used parameters (PAR, temperature) which were observed to have a large influence on methanol (Hörtnagl et al., 2011) for our look-up tables, we observed the mean diurnal variation method to be more successful in filling the data gaps and limit uncertainties even for VOCs which did not show a clear diurnal cycle. According to Fig. 3 this was not only due to the reduced number of data gaps in the half-hourly data set (due to the rejection of days with an insufficient data cover for the daily average methods). Even at a slightly higher percentage of data gaps compared to the daily methods, the mean diurnal cycle method showed clearly the lowest errors for all VOCs. Generally this method makes use of the full range of information saved in the diurnal patterns for missing data replacement in VOC time series, which is most probably the reason for its outstanding performance.

\subsection{Annual VOC budget}

Given the superior performance of the MDV method in the error analysis and the fact that the three best methods produced relatively similar results for the actual data set (Fig. 2), the MDV method was chosen for gap-filling the actual 2009 and 2011 data sets. The wintertime fluxes were estimated by filling the missing days in the winter period with median diurnal cycles (which are less susceptible to outliers than mean values), as calculated from the measurements during 

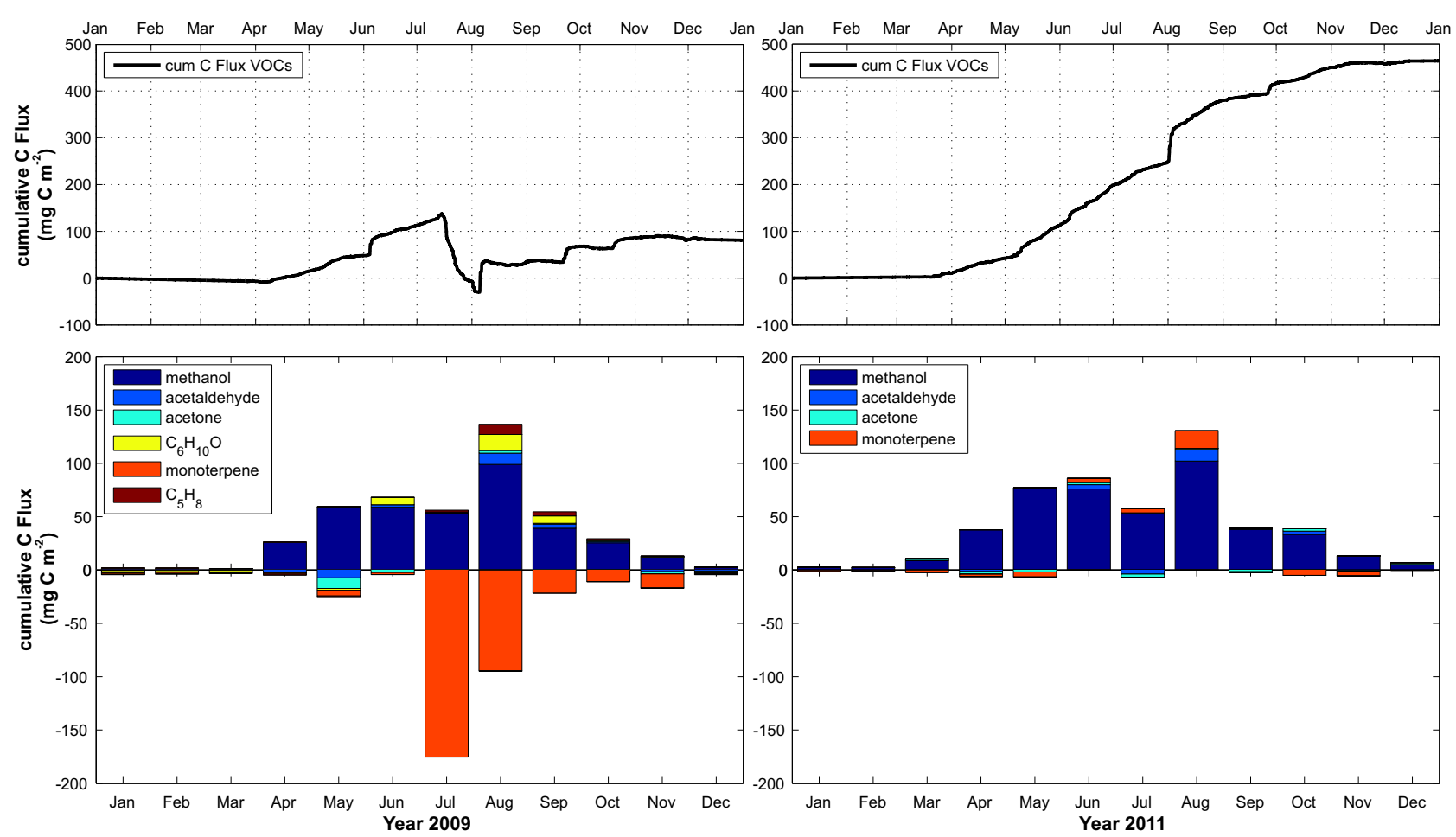

Fig. 4. Time series of the total VOC cumulative carbon flux (upper panels) and the monthly cumulative carbon (C) fluxes (lower panels) for methanol (dark blue), acetaldehyde (blue), acetone (cyan), hexenal $\mathrm{C}_{6} \mathrm{H}_{10} \mathrm{O}$ (yellow), monoterpenes (red), and $\mathrm{C}_{5} \mathrm{H}_{8}$ (bordeaux) for the years 2009 (left panels) and 2011 (right panels).

days with snow cover. Cumulative VOC carbon fluxes for the complete years 2009 and 2011 and the monthly contribution of every VOC to the complete cumulative budget are shown in Fig. 4.

The two main components contributing to the total VOC carbon flux of $81.0 \mathrm{mg} \mathrm{C} \mathrm{m}^{-2}$ in 2009 were methanol $\left(381.5 \mathrm{mg} \mathrm{C} \mathrm{m}^{-2}\right)$ and the sum of monoterpenes $\left(-327.3 \mathrm{mg} \mathrm{C} \mathrm{m}^{-2}\right)$. Fluxes of acetaldehyde $\left(5.5 \mathrm{mg} \mathrm{C} \mathrm{m}^{-2}\right)$, acetone $\left(-12.4 \mathrm{mg} \mathrm{C} \mathrm{m}^{-2}\right)$, the green leaf volatile hexenal measured at $\mathrm{m} / \mathrm{z} 99\left(21.9 \mathrm{mg} \mathrm{C} \mathrm{m}^{-2}\right)$ and an $\mathrm{m} / \mathrm{z}$ 69 fragment of methylbutanals, pentenols and isoprene $\left(11.8 \mathrm{mg} \mathrm{C} \mathrm{m}^{-2}\right)$ were less prominent and their joint contribution to the budget was less than $10 \%$ of the methanol cumulative flux in 2009. Until July the course of the total carbon flux was dominated by the emissions of methanol, which showed continuous emissions from April to November 2009, with highest values in August $\left(99.0 \mathrm{mg} \mathrm{C} \mathrm{m}^{-2}\right.$ ), May $\left(59.2 \mathrm{~m} \mathrm{C} \mathrm{m}^{-2}\right)$ and June $\left(58.8 \mathrm{mg} \mathrm{C} \mathrm{m}^{-2}\right)$. With the date of the hailstorm on 16 July 2009 a strong deposition of monoterpenes started to outweigh the methanol emissions for several weeks. The uptake of monoterpenes was strongest in July $\left(-175.4 \mathrm{mg} \mathrm{C} \mathrm{m}^{-2}\right)$ and August $\left(-94.6 \mathrm{mg} \mathrm{C} \mathrm{m}^{-2}\right)$. Significant emissions of acetaldehyde, $m / z 99\left(\mathrm{C}_{6} \mathrm{H}_{10} \mathrm{O}\right)$ and $m / z 69\left(\mathrm{C}_{5} \mathrm{H}_{8}\right)$ were predominantly detected during the months of cutting (June, August and September 2009). While $\mathrm{m} / z 59$ (acetone) emissions were quite small (even for the cutting months), we observed acetone deposition fluxes of $-9.8 \mathrm{~m} \mathrm{C} \mathrm{m}^{-2}$ in May 2009 and to a lesser degree also in June and November. Acetaldehyde deposition fluxes were highest in May 2009, at $-7.4 \mathrm{mg} \mathrm{C} \mathrm{m}^{-2}$, but were also observed in April and November 2009. Acetaldehyde fluxes were highly variable, however, and showed periods of emission as well as periods of uptake (Hörtnagl et al., 2013).

During the year 2011 cumulative fluxes behaved differently, especially with regard to the contribution of single compounds to the overall VOC balance, which resulted in emissions of $464 \mathrm{mg} \mathrm{C} \mathrm{m}^{-2}$ into the atmosphere (Fig. 3). The monoterpenes, which were one of the major drivers in 2009 flux patterns, had only a small influence $\left(2.7 \mathrm{mg} \mathrm{C} \mathrm{m}^{-2}\right)$ on the overall balance in 2011. Methanol was the major driving compound for VOC carbon fluxes in 2011, with emissions of $449.9 \mathrm{mg} \mathrm{C} \mathrm{m}^{-2}$, showing the highest emissions from May to August $\left(76.2 \mathrm{mg} \mathrm{C} \mathrm{m}^{-2}, 76.0 \mathrm{mg} \mathrm{C} \mathrm{m}^{-2}, 53.6 \mathrm{mg} \mathrm{C} \mathrm{m}^{-2}\right.$, $102.1 \mathrm{mg} \mathrm{C} \mathrm{m}^{-2}$ ). During 2011 contributions of acetaldehyde to the emissions were mainly visible during June, August, September (cutting months) and October (compare to Fig. 4). Monoterpene emissions were only observed in the summer period (June, July, August). Apart from cutting emissions the monoterpenes, acetaldehyde and acetone tended to show small deposition values rather than emissions. Fluxes during the winter period (December till March) were generally low. 
Cumulative methanol fluxes were significantly higher in 2011 compared to 2009. One possible reason for this are the generally warmer $\left(7.1^{\circ} \mathrm{C}\right.$ opposed to $6.8^{\circ} \mathrm{C}$ average air temperature), slightly drier (543 opposed to $576 \mathrm{~mm}$ rainfall), and sunnier (1754 compared to 1546 sun hours) weather conditions, and especially the dry spring in 2011 compared to 2009. The contribution of the hexenal group $\mathrm{C}_{6} \mathrm{H}_{10} \mathrm{O}$ (21.9 $\mathrm{mg} \mathrm{C} \mathrm{m}^{-2}$ in 2009) and $\mathrm{m} / z 69 \mathrm{C}_{5} \mathrm{H}_{8}\left(11.8 \mathrm{mg} \mathrm{C} \mathrm{m}^{-2}\right.$ in 2009) to the overall balance of the VOCs is missing for 2011, suggesting that overall VOC fluxes are between 30 and $40 \mathrm{mg} \mathrm{C} \mathrm{m}^{-2}$ higher in 2011 in addition to the quantified compounds. In general, the estimate of the VOC cumulative carbon flux contains only a restricted set of compounds that includes the most prominent volatiles above grassland. The contribution of other compounds to the VOC carbon balance is thought to be relatively small compared to the overall cumulative flux.

Our quantification of the overall VOC balance from the meadow is, at $81.0 \mathrm{mg} \mathrm{C} \mathrm{m}^{-2}$ and $464.6 \mathrm{mg} \mathrm{C} \mathrm{m}^{-2}$ in 2009 and 2011, respectively, a lot lower than the complete annual exchange of carbon in the form of VOCs above a ponderosa pine plantation which was estimated to range between 6.2 and $12.5 \mathrm{~g} \mathrm{C} \mathrm{m}^{-2}$ (Bouvier-Brown et al., 2012). Irrespective of substantial deposition fluxes during 2009, the dominance of methanol ( $\mathrm{a} \mathrm{C}_{1}$ compound) for the grassland emissions during an average year, in contrast to continuous emissions of $\mathrm{C}_{5}$ and $\mathrm{C}_{10}$ compounds at the ponderosa pine plantation, leads to substantially lower carbon emissions for the grassland site.

\section{Summary and conclusions}

Four different gap-filling procedures were examined with respect to their performance for filling gaps in long-term VOC flux data series. The mean diurnal variation method showed superior performance in filling data gaps, introducing the lowest errors to the data for all VOCs. Applying gap-filling methods on daily average fluxes resulted, regardless of the chosen approach, in considerably larger errors. Accounting for meteorological information by creating daily look-up tables to fill data gaps did not entail a clear advantage over gap-filling using mean values within a gliding window. Gapfilling using simple linear interpolation resulted in the highest errors. The simulation of the error introduced as a consequence of the gap-filling after an artificial increase in the percentage of data gaps revealed a nearly linear increase in the errors with the percentage of missing data. In order to control errors, gap-filling during management actions require separate filling procedures. Highest uncertainties regarding the annual VOC balance, however, were introduced by the filling of the winter period, which is a consequence of an insufficient number of measurements during periods of snow cover and the gap in scientific understanding during these conditions. To assure a better quantification of cumulative
VOC fluxes, the trend should move away from short periods of measurements in campaign style towards a year-round quantification of VOC fluxes including winter periods.

As a result of the gap-filling we presented a complete annual time series for two years of measured VOC fluxes including management events and winter data above a mountain meadow in Austria. We saw a striking difference in the overall annual course of cumulative VOC fluxes. This difference was a consequence of a severe hailstorm in 2009 leading to exceptionally high ambient concentrations of monoterpenes and considerable monoterpene deposition $\left(-327.3 \mathrm{mg} \mathrm{C} \mathrm{m}^{-2}\right)$ onto the meadow, which would not have been reproduced by the current generation of VOC emission models. Annual cumulative VOC fluxes were quantified to be only $81.0 \mathrm{mg} \mathrm{C} \mathrm{m}^{-2}$ in the year 2009 as opposed to $464.6 \mathrm{mg} \mathrm{C} \mathrm{m}^{-2}$ during 2011. Methanol (2009: $381.5 \mathrm{mg} \mathrm{C} \mathrm{m}^{-2}$ and 2011: $449.9 \mathrm{mg} \mathrm{C} \mathrm{m}^{-2}$ ) was the most important compound driving VOC carbon emissions during both years, monoterpene the major compound driving VOC uptake in 2009. VOC fluxes of green leaf volatile hexenal found at $m / z 99$ and fragments of methylbutanals, pentenols (and isoprene) found at $m / z$ 69, which showed to net emissions during cutting and close-to-zero fluxes otherwise, were not quantified in 2011 and can be expected to lead to an additional increase in the 2011 emissions. Our results underline that the current approach of a quantification of only the VOCs, which are a priori thought to contribute to the emissions during short periods of time, will probably limit the progress in understanding the complete VOC balance and thus the NECB.

Acknowledgements. We acknowledge the Austrian National Science Fund and the Tyrolean Science Fund for financial support under project numbers P19849-B16 and P23267-B16 and Uni404/486 and Uni404/1083, respectively. Furthermore, the study was supported by the Translational Research Programme (L518-N20) of the Austrian National Science Fund and the Industry-Academia Partnerships and Pathways (IAPP; 218065) funded by the European Commission. We express our gratitude to the Hofer family (Neustift, Austria), who granted the access to the study site. Additionally, we want to acknowledge Martin Breitenlechner, Martin Graus, Irina Herdlinger-Blatt, Markus Müller, Taina Ruuskanen and Ralf Schnitzhofer for recurrent support at the field site.

Edited by: X. Wang

\section{References}

Atkinson, R.: Atmospheric chemistry of VOCs and NOx, Atmos. Environ., 34, 2063-2101, 2000.

Bamberger, I., Hörtnagl, L., Schnitzhofer, R., Graus, M., Ruuskanen, T. M., Müller, M., Dunkl, J., Wohlfahrt, G., and Hansel, A.: BVOC fluxes above mountain grassland, Biogeosciences, 7, 1413-1424, doi:10.5194/bg-7-1413-2010, 2010. 
Bamberger, I., Hörtnagl, L., Ruuskanen, T. M., Schnitzhofer, R., Müller, M., Graus, M., Karl, T., Wohlfahrt, G., and Hansel, A.: Deposition fluxes of terpenes over grassland, J. Geophys. Res.Atmos., 116, 1-13, 2011.

Bouvier-Brown, N. C., Schade, G. W., Misson, L., Lee, A., McKay, M., and Goldstein, A. H.: Contributions of biogenic volatile organic compounds to net ecosystem carbon flux in a ponderosa pine plantation, Atmos. Environ., 60, 527-533, 2012.

Brilli, F., Hörtnagl, L., Bamberger, I., Schnitzhofer, R., Ruuskanen, T. M., Hansel, A., Loreto, F., and Wohlfahrt, G.: Qualitative and quantitative characterization of volatile organic compound emissions from cut grass., Environ. Sci. Technol., 46, 3859-3865, 2012

Brunner, A., Ammann, C., Neftel, A., and Spirig, C.: Methanol exchange between grassland and the atmosphere, Biogeosciences, 4, 395-410, doi:10.5194/bg-4-395-2007, 2007.

Chapin, F. S., Woodwell, G. M., Randerson, J. T., Rastetter, E. B., Lovett, G. M., Baldocchi, D. D., Clark, D. a., Harmon, M. E., Schimel, D. S., Valentini, R., Wirth, C., Aber, J. D., Cole, J. J., Goulden, M. L.,Harden, J. W. , Heimann, M. Howarth, R. W., Matson, P. A., McGuire, A. D., Melillo, J. M., Mooney, H. A., Neff, J. C.,Houghton, R. A., Pace, M. L., Ryan, M. G., Running, S. W., Sala, O. E., Schlesinger, W. H., and Schulze, E.-D.: Reconciling Carbon-cycle Concepts, Terminol. Methods Ecosyst., 9, 1041-1050, 2006.

Dengel, S., Zona, D., Sachs, T., Aurela, M., Jammet, M., Parmentier, F. J. W., Oechel, W., and Vesala, T.: Testing the applicability of neural networks as a gap-filling method using $\mathrm{CH}_{4}$ flux data from high latitude wetlands, Biogeosciences, 10, 8185-8200, doi:10.5194/bg-10-8185-2013, 2013.

Falge, E., Baldocchi, D., Olson, R., Anthoni, P., Aubinet, M., Bernhofer, C., Burba, G., Ceulemans,R., Clement, R., Dolman, H., Granier, A., Gross, P., Grünwald, T., Hollinger, D., Jensen, N.-O., Katul, G., Keronen, P., Kowalski, A., Ta, C., Law, B. E., Meyers, T., Moncrieff, J., Moors, E., Munger, J. W., Pilegaard, K., Rannik, Ü., Rebmann, C., Suyker, A., Tenhunen, J., Tu, K., Verma, S., Vesala, T.,Wilson, K., and Wofsy, S.: Gap filling strategies for defensible annual sums of net ecosystem exchange, Agr. Forest Meteorol., 107, 43-69, 2001a.

Falge, E., Baldocchi, D., Olson, R., Anthoni, P., Aubinet, M., Bernhofer, C., Burba, G., Ceulemans, R., Clement, R., Dolman, H., Granier, A., Gross, P., Grünwald, T., Hollinger, D., Jensen, N.-O., Katul, G., Keronen, P., Kowalski, A., Ta, C., Law, B. E., Meyers, T., Moncrieff, J., Moors, E., Munger, J. W., Pilegaard, K., Rannik, Ü., Rebmann, C., Suyker, A., Tenhunen, J., Tu, K., Verma, S., Vesala, T., Wilson, K., and Wofsy, S.: Gap filling strategies for long term energy flux data sets, Agr. Forest Meteorol., 107, 71-77, 2001b.

Fall, R., Karl, T., Jordan, A. and Lindinger, W.: Volatile organic compounds emitted after leaf wounding: On-line analysis by proton-transfer-reaction mass spectrometry, J. Geophys. Res., 104, 15963-15974, 1999.

Fall, R., Karl, T., Jordan, A., and Lindinger, W.: Biogenic C5 VOCs: Release from leaves after freeze-thaw wounding and occurrence in air at a high mountain observatory, Atmos. Environ., 35, 39053916, 2001.

Foken, T. and Wichura, B.: Tools for quality assessment of surfacebased flux measurements, Agr. Forest Meteorol., 78, 83-105, 1996.
Forster, P., Ramaswamy, V., Artaxo, P., Berntsen, T., Betts, R., Fahey, D. W., Haywood, J., Lean, J., Lowe, D. C., Myhre, G., Nganga, J., Prinn, R., Raga, G., Schulz, M., and Van Dorland, R.: Changes in atmospheric constituents and in radiative forcing, in: Climate Change 2007: The Physical Science Basis, Contribution of Working Group I to the Fourth Assessment Report of the Intergovernmental Panel on Climate Change, edited by: Solomon, S., Qin, D., Manning, M., Chen, Z., Marquis, M., Averyt, K. B., Tignor, M., and Miller, H. L., CambridgeUniversity Press, Cambridge, UK, New York, NY, USA, 2007.

Goldstein, A. H. and Galbally, I. E.: Known and Unexplored organic constituents in the Earth's atmosphere, Environ. Sci. Technol., 41, 1515-1521, 2007.

Guenther, A. B., Zimmerman, P. R., Harley, P. C., Monson, R. K., and Fall, R.: Isoprene and Monoterpene Emission Rate Variability: Model Evaluations and Sensitivity Analyses, J. Geophys. Res., 98, 12609-12617, 1993.

Guenther, A., Hewitt, N. C., Erickson, D., Fall, R., Geron, C., Graedel, T., Harley, P., Klinger, L., Lerdau, M., McKay, W. A., Pierce, T., Scholes, B., Steinbrecher, R., Tallamraju, R., Taylor, J., and Zimmerman, P.: A global model of natural volatile organic compound emissions, J.Geophys. Res., 100, 8873-8892, 1995.

Hallquist, M., Wenger, J. C., Baltensperger, U., Rudich, Y., Simpson, D., Claeys, M., Dommen, J., Donahue, N. M., George, C., Goldstein, A. H., Hamilton, J. F., Herrmann, H., Hoffmann, T., Iinuma, Y., Jang, M., Jenkin, M. E., Jimenez, J. L., Kiendler-Scharr, A., Maenhaut, W., McFiggans, G., Mentel, Th. F., Monod, A., Prévôt, A. S. H., Seinfeld, J. H., Surratt, J. D., Szmigielski, R., and Wildt, J.: The formation, properties and impact of secondary organic aerosol: current and emerging issues, Atmos. Chem. Phys., 9, 5155-5236, 2009, http://www.atmos-chem-phys.net/9/5155/2009/.

Hammerle, A., Haslwanter, A., Tappeiner, U., Cernusca, A., and Wohlfahrt, G.: Leaf area controls on energy partitioning of a temperate mountain grassland, Biogeosciences, 5, 421-431, doi:10.5194/bg-5-421-2008, 2008.

Hansel, A., Jordan, A., Holzinger, R., Prazeller, P., Vogel, W., and Lindinger, W.: Proton transfer reaction mass spectrometry: online trace gas analysis at the ppb level, Int. J. Mass Spectrom., 149/150, 609-619, 1995.

Hörtnagl, L., Bamberger, I., Graus, M., Ruuskanen, T. M., Schnitzhofer, R., Müller, M., Hansel, A., and Wohlfahrt, G.: Biotic, abiotic, and management controls on methanol exchange above a temperate mountain grassland, J. Geophys. Res., 116, G03021, doi:10.1029/2011JG001641, 2011.

Hörtnagl, L., Bamberger, I., Graus, M., Ruuskanen, T. M., Schnitzhofer, R., Walser, M., Unterberger, A., Hansel, A., and Wohlfahrt, G.: Acetaldehyde exchange above a managed temperate mountain grassland, Atmos. Chem. Phys. Discuss., 13, 26117-26174, doi:10.5194/acpd-13-26117-2013, 2013.

Hsieh, C.-I., Katul, G., and Chi, T.: An approximate analytical model for footprint estimation of scalar fluxes in thermally stratified atmospheric flows, Adv. Water Resour., 23, 765-772, 2000.

Kaimal, J. C. and Finnigan, J. J.: Atmospheric Boundary Layer Flows, Oxford University Press, Oxford, 289 pp., 1994.

Karl, T., Guenther, A., Lindinger, C., Jordan, A., Fall, R., and Lindinger, W.: Eddy covariance measurements of oxygenated volatile organic compound fluxes from crop harvesting using a 
redesigned proton-transfer-reaction mass spectrometer, J. Geophys. Res., 106, 24157-24167, 2001.

Karl, T. G., Spirig, C., Rinne, J., Stroud, C., Prevost, P., Greenberg, J., Fall, R., and Guenther, A.: Virtual disjunct eddy covariance measurements of organic compound fluxes from a subalpine forest using proton transfer reaction mass spectrometry, Atmos. Chem. Phys., 2, 279-291, doi:10.5194/acp-2-279-2002, 2002.

Karl, T., Guenther, A., Spirig, C., Hansel, A., and Fall, R.: Seasonal variation of biogenic VOC emissions above a mixed hardwood forest in northern Michigan, Geophys. Res. Lett., 30, 2186, doi:10.1029/2003GL018432, 2003.

Karl, T., Potosnak, M., and Guenther, A.: Exchange processes of volatile organic compounds above a tropical rain forest: Implications for modeling tropospheric chemistry above dense vegetation, J. Geophys. Res., 109, D18306, doi:10.1029/2004JD004738, 2004.

Kaser, L., Karl, T., Guenther, A., Graus, M., Schnitzhofer, R., Turnipseed, A., Fischer, L., Harley, P., Madronich, M., Gochis, D., Keutsch, F. N., and Hansel, A.: Undisturbed and disturbed above canopy ponderosa pine emissions: PTR-TOF-MS measurements and MEGAN 2.1 model results, Atmos. Chem. Phys., 13, 11935-11947, 2013, http://www.atmos-chem-phys.net/13/11935/2013/.

Laffineur, Q., Aubinet, M., Schoon, N., Amelynck, C., Müller, J.-F., Dewulf, J., Van Langenhove, H., Steppe, K., and Heinesch, B.: Abiotic and biotic control of methanol exchanges in a temperate mixed forest, Atmos. Chem. Phys., 12, 577-590, 2012, http://www.atmos-chem-phys.net/12/577/2012/.

Laffineur, Q., Aubinet, M., Schoon, N., Amelynck, C., Müller, J.-F., Dewulf, J., Van Langenhove, H., Steppe, K., Šimpraga, M., and Heinesch, B.: Isoprene and monoterpene emissions from a mixed temperate forest, Atmos. Environ., 45, 3157-3168, 2011.

Laothawornkitkul, J., Taylor, J. E., Paul, N. D., and Hewitt, C. N.: Biogenic volatile organic compounds in the Earth system., New Phytol., 183, 27-51, 2009.

Lathiere, J., Hauglustaine, D. A., Friend, A. D., De NobletDucoudre, N., Viovy, N., and Folberth, G. A.: Impact of climate variability and land use changes on global biogenic volatile organic compound emissions, Atmos. Chem. Phys., 6, 2129-2146, doi:10.5194/acp-6-2129-2006, 2006.
Lindinger, W., Hansel, A., and Jordan, A.: On-line monitoring of volatile organic compounds at pptv levels by means of ProtonTransfer-Reaction Mass Spectrometry (PTR-MS) Medical applications, food control and environmental research, Int. J. Mass Spectrom., 173, 191-241, 1998.

McMillen, R. T.: An eddy correlation technique with extended applicability to non-simple terrain, Bound.-Lay. Meteorol., 43, 231-245, 1988.

Mishurov, M. and Kiely, G.: Gap-filling techniques for the annual sums of nitrous oxide fluxes, Agr. Forest Meteorol., 151, 17631767, 2011.

Moffat, A. M., Papale, D., Reichstein, M., Hollinger, D. Y., Richardson, A. D., Barr, A. G., Beckstein, C., Braswell, B. H., Churkina, G., Desai, A. R., Falge, E., Gove, J. H., Heimann, M., Hui, D., Jarvis, A. J., Kattge, J., Noormets, A., and Stauch, V. J.: Comprehensive comparison of gap-filling techniques for eddy covariance net carbon fluxes, Agr. Forest Meteorol., 147,209-232, 2007.

Novick, K. A., Stoy, P. C., Katul, G. G., Ellsworth, D. S., Siqueira, M. B. S., Juang, J., and Oren, R.: Carbon dioxide and water vapor exchange in a warm temperate grassland, Oecologia, 138, 259274, 2004.

Reichstein, M., Falge, E., Baldocchi, D., Papale, D., Aubinet, M., Berbigier, P., Bernhofer, C., Buchmann, N., Gilmanov, T., Granier, A., Grünwald, T., Havránková, K., Ilvesniemi, H., Janous, D., Knohl, A., Laurila, T., Lohila, A., Loustau, D., Matteucci, G., Meyers, T., Miglietta, F., Ourcival, J.-M., Pumpanen, J., Rambal, S., Rotenberg, E., Sanz, M., Tenhunen, J., Seufert, G., Vaccari, F., Vesala, T., Yakir, D., and Valentini, R.: On the separation of net ecosystem exchange into assimilation and ecosystem respiration: review and improved algorithm, Glob. Change Biol., 11, 1424-1439, 2005.

Ruuskanen, T. M., Müller, M., Schnitzhofer, R., Karl, T., Graus, M., Bamberger, I., Hörtnagl, L., Brilli, F., Wohlfahrt, G., and Hansel, A.: Eddy covariance VOC emission and deposition fluxes above grassland using PTR-TOF, Atmos. Chem. Phys., 11, 611-625, doi:10.5194/acp-11-611-2011, 2011.

Wohlfahrt, G., Hammerle, A., Haslwanter, A., Bahn, M., Tappeiner, U., and Cernusca, A.: Seasonal and inter-annual variability of the net ecosystem $\mathrm{CO}_{2}$ exchange of a temperate mountain grassland: Effects of weather and management, J. Geophys. Res., 113, D08110, doi:10.1029/2007JD009286, 2008. 